\title{
Personal meaning of work and perceived work ability among middle- aged workers with physically strenuous work: a Northern Finland Birth Cohort 1966 Study
}

\author{
Anne Punakallio ${ }^{1}$ (D) Sirpa Lusa ${ }^{1}$. Leena Ala-Mursula ${ }^{2}$ Ellen Ek ${ }^{2} \cdot$ Nina Nevanperä $^{1} \cdot$ Jouko Remes $^{1}$. \\ Juha Auvinen $^{2,3} \cdot$ Jorma Seitsamo $^{1} \cdot$ Jaro Karppinen $^{1,2,3} \cdot$ Jaana Laitinen $^{1}$
}

Received: 13 June 2017 / Accepted: 24 January 2019 / Published online: 14 February 2019

(c) The Author(s) 2019

\begin{abstract}
Purpose To investigate the association between personal meaning of work and perceived work ability among middle-aged workers with physically strenuous or light work. We evaluated the course of perceived work ability from 31 to 46 years and examined the possible differences in the association between personal meaning of work and perceived work ability at the age of 46 depending on physical workload.

Methods The study population consisted of participants of the Northern Finland Birth Cohort $1966(n=4420)$. Data were collected through questionnaires at 31 and 46 years. The main outcome was perceived work ability $(0-7=$ poor, $8-10=$ good $)$ and the main explanatory measures were physically strenuous work and personal meaning of work. Multivariate logistic regression analyses were adjusted for unhealthy habits, number of diseases, job strain, social support at work, employment history and gender. They were also stratified for the strenuousness of work.

Results Perceived work ability decreased during the 15-year follow-up in both the strenuous and light work groups, and was lowest among workers with strenuous work. Perceived work ability remained poor or decreased in $22 \%$ of men and $21 \%$ of women in the strenuous work group vs. $14 \%$ and $13 \%$ in the light work group, respectively. After adjusting for confounders, the participants in both groups who reported low personal meaning of work were at approximately a twofold risk of having poor perceived work ability at 46 years compared to the participants who reported high personal meaning of work.

Conclusions Perceived work ability was significantly lower and deteriorated more during the follow-up among participants with strenuous work. High personal meaning of work was important for good work ability, irrespective of the strenuousness of work.
\end{abstract}

Keywords Birth cohort $\cdot$ Work ability $\cdot$ Personal meaning of work $\cdot$ Physically strenuous work $\cdot$ Longitudinal study

\section{Introduction}

The need to extend working careers is serious in western societies, due to the changed age structure of the populations (Eurostat, New Cronos, http://ec.europa.eu/eurostat/data/

Anne Punakallio

anne.punakallio@ttl.fi

1 Finnish Institute of Occupational Health, PO Box 40, 00032 Työterveyslaitos, Helsinki, Finland

2 Center for Life Course Health Research, University of Oulu, Oulu, Finland

3 Medical Research Center Oulu, Oulu University Hospital and University of Oulu, Oulu, Finland database). Work ability is an important determinant of the length of working careers, and poor work ability in midlife predicts disability severity years later (von Bonsdorff et al. 2012), sickness absences (Sell et al. 2009) and early retirement (Roelen et al. 2014). Maintaining the work ability of employees is an important prerequisite for preventing early exit from work and for increasing productivity (Ilmarinen 2006).

The concept of work ability has many complex, holistic and dynamic aspects (for a scoping review, see Lederer et al. 2014). One way of conceptualizing and visualizing it is the "Work Ability House", which has four floors indicating four dimensions of work ability that interact with each other (Ilmarinen et al. 2005) (Fig. 1). In this conceptualization, health, health habits, physical and mental capacities form the 
Work Ability House

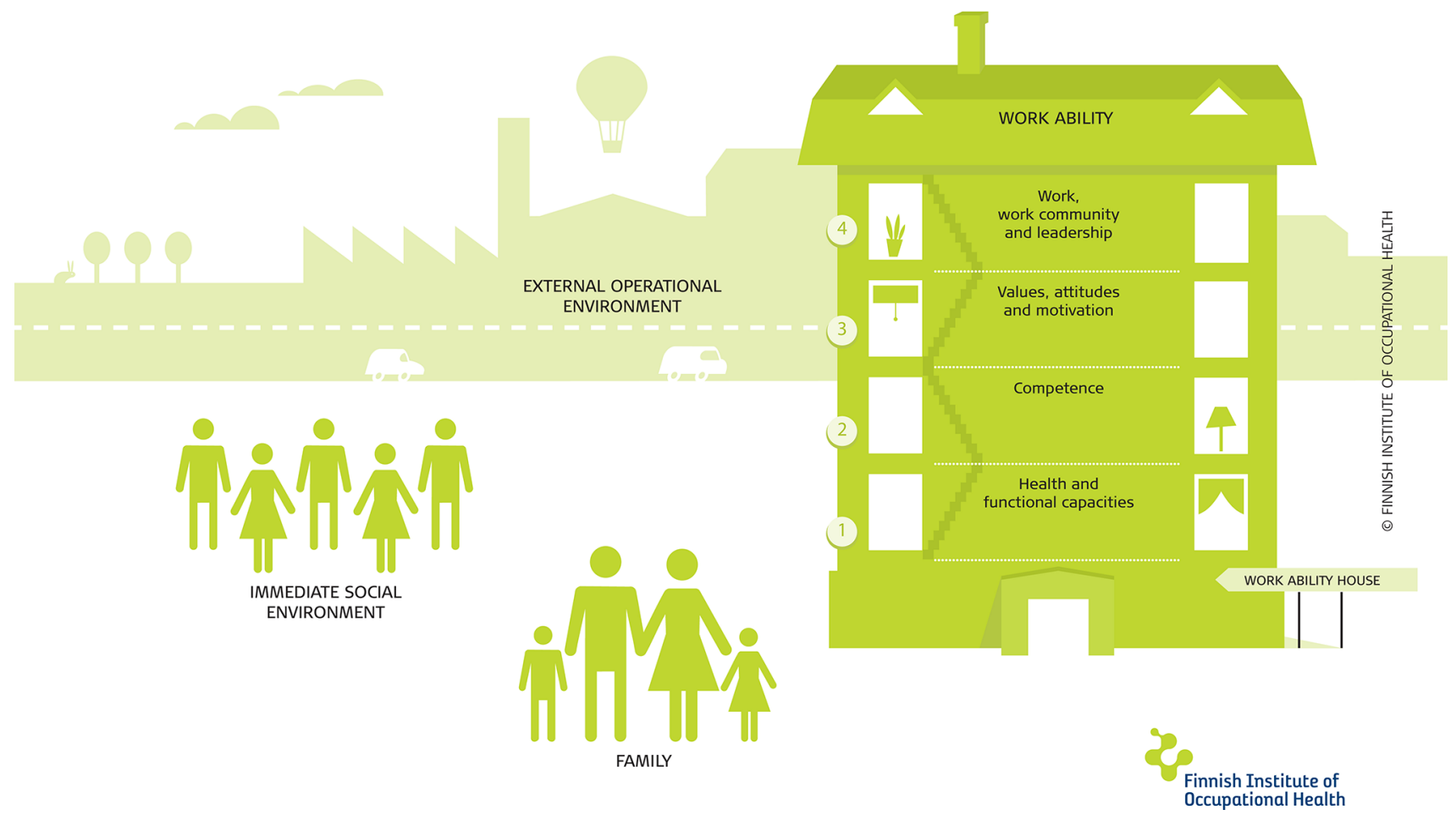

Fig. 1 The Work Ability House (Ilmarinen et al. 2005)

basic floor. The other floors are comprised of occupational competence; of personal aspects such as values, attitudes and motivation; and last, of work itself, including the content and demands of work, the work environment, the community and the organization. In addition, external circumstances related to family, the social environment and the (macroeconomic) circumstances in the economy and society influence a worker's work ability.

Empirically, studies have shown that the ground floor of health and functional capacities, and the floor of workrelated factors have the strongest effect on work ability, especially among older workers (Gould et al. 2008; Ilmarinen et al. 2005). In general, the floor consisting of values, attitudes and motivational factors, including personal meaning of work, has not received much attention in the research on work ability. The personal sense of meaning in any domain is, however, fundamental in all human intentional action (Frankl 1963; O'Connor and Chamberlain 1996). According to Kahn and Wiener (1967), work can fulfil the need for short- or long-term income, and at the same time it can satisfy internal values such as exercising and mastering gratifying skills, participating in an important activity, self-identification and self-fulfilment. Kahn and Wiener also propose that there are individual differences in how these work-related gains are perceived and valued, resulting in differing levels of personal meaning of work in an individuals' life.

In terms of opportunities to support work ability, the floor of work, including physical and psychosocial work environment and physical work demands, entitles a natural platform for work-related actions, and advancing technologies have indeed been helpful in the overall reduction of physical work demands during the last decades. Still, it is not always possible to avoid excessive physical workload or demanding postures. Even to date, work demands may remain physically hard. Early retirement due to loss of work ability is most common in physically demanding occupations (Pensola et al. 2010). Among middle-aged workers (mean 47, range 44-51 years), work ability decreased more in physical work than in mental work over an 11-year follow-up (Ilmarinen et al. 1997). The decrease was more significant among the oldest workers (over 51 years), the highest in physically strenuous work and the lowest in mentally strenuous work (Ilmarinen et al. 1997). However, whether the early development of work ability up to midlife differs between those with and without physically strenuous work is not as well known.

The increased risk of work disability among those with physically strenuous work can be due to many reasons. It 
may relate to selection to physically strenuous work, to educational or lifestyle factors, or to high physical strain itself (Punakallio et al. 2014; von Bonsdorff et al. 2011). A combination of obesity-related diseases and physically strenuous work has been shown to have a cumulative deleterious effect on work ability (Gould et al. 2008). Lack of vigorous physical activity in leisure time, obesity, psychosocial work-related factors such as high mental work demands, lack of autonomy, poor task resources, poor leadership and relationships between workers and supervisors, as well as lack of social support, poor physical work environment, and high physical workload have all been associated with poor work ability (Airila et al. 2012; Lusa et al. 2011; Nevanperä et al. 2015, 2016; van den Berg et al. 2009). In addition, poor musculoskeletal capacity, motor coordination and balance, and work accidents and poor working postures may lead to decreased work ability among workers in physically demanding occupations (Lusa et al. 2011; Punakallio et al. 2011).

A recent study observed that the task-based work engagement was positively associated with work ability even after adjusting for age, life habits and working conditions among workers with a heavy physical workload (Airila et al. 2012). Analogously, low perceived meaning at work, operationalized as a feeling that work is not important, not meaningful, and not feeling motivated and engaged in one's work, was associated with earlier disability pensioning (Clausen et al. 2014). Instead, less is known of the relevance of more personal meaning of work for work ability in physically strenuous work. To our knowledge, no previous longitudinal study has explored whether the associations between personal meaning of work and work ability differ among workers doing physically strenuous or light work.

The goal of this study was to examine the association between the personal meaning of work and perceived work ability among middle-aged participants with and without physically strenuous work. The specific aims were: (1) to evaluate the development of work ability from 31 to 46 years in physically strenuous compared to light work and (2) to describe any differences in the association between the personal meaning of work and work ability among workers with and without physically strenuous work.

\section{Methods}

\section{Study population and data collection}

The ongoing Northern Finland Birth Cohort (NFBC) 1966 started with a study population comprising $96.3 \%$ of all births during 1966 in the areas of Oulu and Lapland, and was followed up for 46 years (Rantakallio 1969, 1988) (Fig. 2).
In the 31-year follow-up in 1997, a postal questionnaire was sent to participants who were alive and had a known address $(n=11,541)$, and $75.3 \%$ responded (Järvelin et al. 2004). Cohort members who lived in Northern Finland or in the metropolitan area $(n=8463)$ were invited to a clinical examination, during which they were asked to reply to a questionnaire about work life. Of these, $67.5 \%$ $(n=5713)$ responded. In the 46-year follow-up, 10,321 participants were alive and traced, and asked by letter to fill in web-based questionnaires. If the participants had no computer or preferred answering on paper, they were sent a postal questionnaire. Answers were received from $67.4 \%$ $(n=6932)$ of all invited participants.

The final study population included those participants whose data on the studied variables at 31 and 46 years were available ( $n=4420)$ (Fig. 2). The effect of potential selection bias was studied by comparing the distribution of some variables of those included in the results to those excluded from the analyses due to missing data.

\section{Compliance with ethical standards}

All participants gave a written informed consent in accordance with the Declaration of Helsinki 1975, as revised in 2000 , at each stage of the study. The study was approved by the Ethics Committee of the Northern Ostrobothnia Hospital District.

\section{Outcome measure}

Current perceived work ability compared to lifetime best was used as the outcome measure. The participants evaluated their current perceived work ability on a scale of $0-10$ at the ages of 31 and 46, 10 indicating lifetime best work ability. The question used for this was the first item of the Work Ability Index (Tuomi et al. 1991, 1997, 2006). Current perceived work ability is a reliable and valid indicator of work ability (de Zwart et al. 2002; van den Berg et al. 2009; Tuomi et al. 1998). It has associated strongly with the whole Work Ability Index and predicted mental and physical work strain in midlife and disability after retirement (Ahlström et al. 2010; el Fassi et al. 2013; Ilmarinen and Tuomi 2004; von Bonsdorff et al. 2011, 2012).

Current perceived work ability was first classified into two groups: good (8-10) and poor (0-7). Second, to describe perceived work ability from 31 to 46 years, the item was divided into four groups: always good (8-10), deteriorated (from $8-10$ to $0-7$ ), improved (from $0-7$ to $8-10)$, and always poor $(0-7)$. 
Fig. 2 Flowchart of the Northern Finland Birth Cohort 1966 (Rantakallio 1969, 1988)

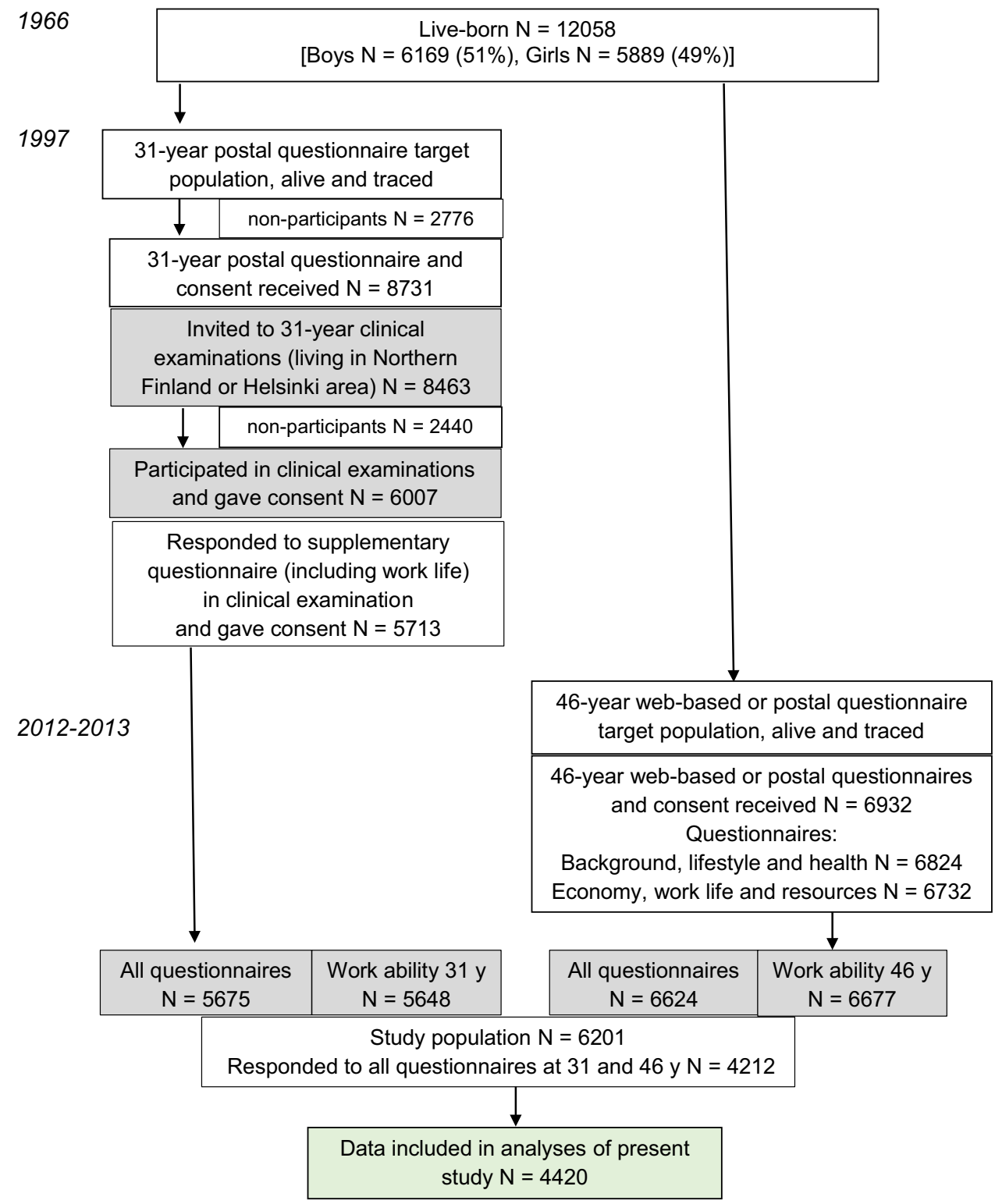

\section{Explanatory measures}

The main explanatory measures were physically strenuous work and personal meaning of work. Physically strenuous work was evaluated at the age of 31 and 46, using the question "To what extent are the following tasks and postures part of your job?" The participants had to evaluate certain tasks and postures in their work, through nine items: "Heavy physical work in which the body has to struggle", "Lifting loads of 1 to $15 \mathrm{~kg}$ ", "Lifting loads over $15 \mathrm{~kg}$ ", "Continuous movement or walking", "Repetitious work movements", "Standing", "Working with the upper arms elevated", "Forward-bent work postures" and "Rotational movements of the trunk". The response scale was from 1 to $5 ; 1$ (not at all or very rarely), 2 (rarely), 3 (moderately), 4 (often), and 5 (very often). The scale was reclassified as physically light work (light work, 1-2) and strenuous work (strenuous work, 3-5). We summed the recoded answers of nine questions and divided the scores into two groups, using the median as cut-offs.

Personal meaning of work was evaluated at the age of 46 using the scale introduced by Kahn and Wiener (1967), (Ek et al. 2005) by asking "How well do the following statements apply to you? with six items: "Work is an unpleasant necessity for earning money"; "Work brings you satisfaction, because you learn to use different occupational skills"; "Work is important, because it gives you experiences of accomplishment and progress"; "Work is a calling that allows you to fulfil yourself"; and "Work is the purpose of life and allows you to accomplish significant things". The response scale was from 1 to $5 ; 1$ (very little), 2 (little), 3 (moderately), 4 (much) and 5 (very much) and the first item 
was used as reversed. Cronbach's alpha for the scale was 0.798 . Next, we recoded the values $1=0,2=1,3=2,4=3$, $5=4$ and calculated the sum variable using the recoded values. Finally, the sum scores were divided into three groups, using the tertiles as cut-offs; $1=0-10$ (low), $2=11-14$ (medium), $3=\geq 15$ (high).

\section{Covariates}

Multivariate analyses were adjusted for job strain and social support at work, representing the floor of work in the Work Ability House, for self-reported employment history indicating the participant's attachment to work, as well as for number of diseases and health habits in reflection of the basic floor of health in the Work Ability House. The selection of poor health habits (leisure time physical inactivity, smoking, alcohol consumption, stress-related eating and drinking) was based on the results of an earlier Finnish populationbased study by Laaksonen et al. (2001). The data on all these covariates were obtained from questionnaires at the age of 46.

Job strain psychosocial job characteristics (i.e. job demands and job control) were evaluated using questions from the Job Content Questionnaire (Karasek et al. 1998). Job demands (11 items) and job control (15) were evaluated on a scale of 1 (very little) to 5 (very much), as previously reported (Kujala et al. 2006). The scores of both characteristics were summed and divided into two groups (high/low), based on median splits. Four further groups were created; high demands and high control (active), high demands and low control (high strain), low demands and high control (low strain), and low demands and low control (passive) (Karasek et al. 1998). Cronbach's alpha values for scales of job control and job demands were 0.88 and 0.90 , respectively.

The amount of social support at work was evaluated using a structured five-point scale that elicited the extent (a lot-not at all) to which the participant received emotional support (listening or advice) or practical support (help with a work task) from coworkers and supervisors (four items). The sum of the four items was calculated and recoded as (1) little or no support, (2) some support, and (3) a great deal of support (Kujala et al. 2006). Cronbach's alpha for the scale was 0.84 .

Employment history was elicited by the question: which of the following seven alternatives (from always continuously employed to never in gainful employment) best describes your employment history? We divided the scores into two groups, using the medians as cut-offs (continuously employed vs. at least temporary unemployed).

Number of diseases was the sum of self-reported physician-diagnosed diseases elicited using the Work Ability Index (Kujala et al. 2005; Tuomi et al. 2006).
Physical activity was evaluated by eliciting participation in light and brisk leisure time physical activity/exercise. Physical activity was classified into three groups: inactive (brisk physical activity less than once a week and light activity less than four times a week), moderately active (brisk physical activity at least once a week but less than $20 \mathrm{~min}$ at a time or light physical activity at least four times a week) and active/very active (brisk physical activity at least two times a week, at least $20 \mathrm{~min}$ at a time) (Tammelin et al. 2003).

Smoking was classified as ex-smoker/never smoked, light smoker (5-6 days a week or occasionally) or smoker (daily smoking).

Alcohol consumption was evaluated on the basis of the frequency of alcohol use (daily to once a year or never) and the usual amount of each alcoholic beverage [beer/cider/ long drink (a Finnish beverage, equal in strength to beer and cider), light wine, table wine and spirits] per drinking occasion (Nevanperä et al. 2016). From these, we calculated the weekly consumption (portions/week) and formed three groups on the basis of the tertile cut-offs. The cut-off points were $<1.5, \geq 1.5$ to $<10$ and $\geq 10$ for men, and $<1, \geq 1$ to $<5$ and $\geq 5$ portions/week for women.

Stress-related eating and drinking is an indicator of a passive coping style and is associated with poor perceived work ability (Nevanperä et al. 2015). This was measured by asking the participants to evaluate if they had tried to relieve feelings of stress by eating, drinking, using medication, etc. the last time they had felt stressed (Folkman and Lazarus 1985; Lazarus and Folkman 1984). This one item of the Ways of Coping Checklist has been used in earlier studies among adolescents and adults (Jääskeläinen et al. 2014; Laitinen et al. 2002). The answers were classified into two groups; no $=0$ (not at all, somewhat) and yes $=1$ (quite a lot or a great deal) (Laitinen et al. 2002). The sum score including stress-related eating was calculated (and divided into two groups; no (sum score of 0 ) and yes (sum score of 1-2).

Health habits included physical inactivity, current smoking, risky alcohol consumption, and stress-related eating and drinking. At the age of 46 , they were further combined and three groups (healthy, between and unhealthy) were formed on the basis of the tertiles of the sum scores (physical inactivity, smoking, alcohol consumption, stress-related eating and drinking).

\section{Statistical analyses}

The statistical analyses were performed using IBM SPSS Statistics 23 for Windows (IBM Corp., Armonk, NY, USA). The course of perceived work ability (0-10) from 31 to 46 years among men and women according to the physical strenuousness of the work were described. The differences between the median perceived work ability values of the 
subgroups were investigated by reporting $95 \%$ confidence intervals (CI) and using the Mann-Whitney- $U$ test.

We used cross-tabulation and chi-square tests to investigate the univariate associations between explanatory variables and perceived work ability at the age 46. Multivariate logistic regression analyses were used to calculate risk ratios (RR) and their $95 \%$ confidence intervals (CI) for poor perceived work ability at 46 years. Personal meaning of work was used as an explanatory variable, and models were adjusted for gender, job strain, social support at work, employment history, health habits, and number of diseases, all at the age of 46 . The analyses were stratified by physical strenuousness of work.

\section{Results}

\section{Work ability from 31 to 46 years}

Perceived work ability at the age of 31 was lower among workers with physically strenuous work than among those with physically light work, among both men and women (Table 1). Perceived work ability decreased during the 15-year follow-up in both groups, and was the lowest among workers with strenuous work. At the age of $46,22 \%$ of men and $20 \%$ of women had poor perceived work ability in the strenuous work group, and $14 \%$ of men and $13 \%$ of women had poor perceived work ability in the light work group, respectively. In the strenuous work group, perceived work ability remained always poor or decreased among $22 \%$ of men and $21 \%$ of women in comparison with $14 \%$ and $13 \%$, respectively, in the light work group (Table 1).

The participants whose work remained strenuous during the whole follow-up period had the worst perceived work ability; men 8.3 (8.2-8.4) and women 8.4 (8.2-8.5). In this group, $23 \%$ of men and $19 \%$ of women remained under the perceived work ability score of 8 , whereas in the group in which the work remained light, $11 \%$ of men and $9 \%$ of women remained perceived work ability under the score of 8 (Table 2). Perceived work ability was the best among participants whose work remained light, at 8.8 (CI 8.7-8.9) among both men and women at the end of follow-up.

\section{Association between personal meaning of work and perceived work ability among participants with physically strenuous and light work}

The participants who reported low personal meaning of work, both in the strenuous and light work groups, were at approximately a twofold risk (strenuous work; 1.96, $1.51-2.54$ vs. light work; $2.11,1.51-2.95$ ) of poor perceived work ability at 46 years compared to the participants who reported good personal meaning of work (Table 3 ). The association between personal meaning of work and poor perceived work ability was significant, even after adjusting for the number of diseases, health habits, job strain, social support at work and employment history. Most of these covariates were also independently related to poor perceived work ability. Reporting two or more diseases, unhealthy habits and low social support at work were associated with poor perceived work ability in both the strenuous work and light
Table 1 Course of perceived work ability (PWA) (0-10) from 31 to 46 years among men and women according to physical strenuousness of work

\begin{tabular}{|c|c|c|c|c|c|c|}
\hline \multicolumn{7}{|c|}{ Physically strenuous work at 31 years } \\
\hline & \multicolumn{3}{|l|}{ Men } & \multicolumn{3}{|l|}{ Women } \\
\hline & Yes & No & $p$ & Yes & No & $p$ \\
\hline \multicolumn{7}{|c|}{ PWA, mean $(95 \%$ CI) } \\
\hline 31 years & $\begin{array}{l}8.7(8.7-8.8) \\
(n=1107)\end{array}$ & $\begin{array}{l}9.0(9.0-9.1) \\
(n=1088)\end{array}$ & & $\begin{array}{l}8.7(8.7-8.8) \\
(n=1058)\end{array}$ & $\begin{array}{l}9.0(8.9-9.1) \\
(n=970)\end{array}$ & \\
\hline 46 years & $\begin{array}{l}8.1(8.0-8.2) \\
(n=790)\end{array}$ & $\begin{array}{l}8.6(8.5-8.7) \\
(n=824)\end{array}$ & & $\begin{array}{l}8.2(8.1-8.4) \\
(n=852)\end{array}$ & $\begin{array}{l}8.6(8.5-8.7) \\
(n=790)\end{array}$ & \\
\hline \multicolumn{7}{|c|}{ Poor PWA, $n(\%)$} \\
\hline 31 years & $120(11)$ & $82(8)$ & & $123(12)$ & $65(7)$ & \\
\hline & & & 0.007 & & & $<0.001$ \\
\hline 46 years & $174(22)$ & $112(14)$ & & $174(20)$ & $99(13)$ & \\
\hline PWA, $n(\%)$ & & & $<0.001$ & & & $<0.001$ \\
\hline Always poor & $32(4)$ & $23(3)$ & & $40(5)$ & $16(2)$ & \\
\hline Deteriorated & $140(18)$ & $87(11)$ & & $132(16)$ & $83(11)$ & \\
\hline Improved & $49(6)$ & $34(4)$ & & $53(6)$ & $33(4)$ & \\
\hline Always good & $557(72)$ & $670(82)$ & & $618(73)$ & $654(83)$ & \\
\hline & & & $<0.001$ & & & $<0.001$ \\
\hline
\end{tabular}


Table 2 Perceived work ability (PWA) $(0-10 ; 0-7=$ poor, $8-10=$ good) among men and women according to course of workload during 15 -year follow-up

Physical strenuousness from 31 years to 46 years

\begin{tabular}{|c|c|c|c|c|c|c|c|}
\hline \multicolumn{4}{|l|}{ Men } & \multicolumn{4}{|l|}{ Women } \\
\hline $\begin{array}{l}\text { Always strenu- } \\
\text { ous }\end{array}$ & $\begin{array}{l}\text { Has become } \\
\text { more strenu- } \\
\text { ous }\end{array}$ & $\begin{array}{l}\text { Has become } \\
\text { lighter }\end{array}$ & Always light & $\begin{array}{l}\text { Always strenu- } \\
\text { ous }\end{array}$ & $\begin{array}{l}\text { Has become } \\
\text { more strenu- } \\
\text { ous }\end{array}$ & $\begin{array}{l}\text { Has become } \\
\text { lighter }\end{array}$ & Always light \\
\hline
\end{tabular}

PWA at 46 years

\begin{tabular}{cllllllll} 
Mean & 8.3 & 8.5 & 8.6 & 8.8 & 8.4 & 8.6 & 8.7 & 8.8 \\
$(95 \% \mathrm{CI})$ & $(8.2-8.4)$ & $(8.4-8.7)$ & $(8.4-8.8)$ & $(8.7-8.9)$ & $(8.2-8.5)$ & $(8.4-8.8)$ & $(8.5-8.9)$ & $(8.7-8.9)$ \\
$0-7, n(\%)$ & $103(20)$ & $33(15)$ & $23(15)$ & $55(11)$ & $105(19)$ & $28(14)$ & $25(13)$ & $46(9)$ \\
$8-10, n(\%)$ & $424(80)$ & $189(85)$ & $132(85)$ & $462(89)$ & $440(81)$ & $172(86)$ & $168(87)$ & $455(91)$ \\
\hline
\end{tabular}

Table 3 Association of personal meaning of work (PMOW) and potential covariates for having poor perceived work ability (PWA 0-7) at the age of 46 among participants in strenuous and light work

\begin{tabular}{|c|c|c|c|c|c|c|}
\hline & \multicolumn{6}{|c|}{ Physically strenuous work } \\
\hline & \multicolumn{3}{|l|}{ Yes } & \multicolumn{3}{|l|}{ No } \\
\hline & PWA $0-7 / n$ & $\mathrm{RR}$ & $95 \% \mathrm{CI}$ & PWA $0-7 / \mathrm{n}$ & RR & $95 \% \mathrm{CI}$ \\
\hline \multicolumn{7}{|l|}{ PMOW } \\
\hline Low & $212 / 896$ & 1.96 & $1.51-2.54$ & $139 / 729$ & 2.11 & $1.51-2.95$ \\
\hline Medium & $95 / 703$ & 1.21 & $0.91-1.61$ & $57 / 676$ & 1.16 & $0.80-1.68$ \\
\hline High & $75 / 709$ & 1.00 & - & $47 / 707$ & 1.00 & - \\
\hline \multicolumn{7}{|l|}{ Covariates } \\
\hline \multicolumn{7}{|l|}{ Number of diseases } \\
\hline$>2$ & $344 / 1460$ & 2.49 & $1.81-3.43$ & $226 / 1637$ & 3.64 & $2.25-5.89$ \\
\hline $0-1$ & $38 / 504$ & 1.00 & - & $17 / 475$ & 1.00 & - \\
\hline \multicolumn{7}{|l|}{ Health habits } \\
\hline Unhealthy & $187 / 903$ & 1.60 & $1.28-1.99$ & $90 / 646$ & 1.30 & $1.00-1.70$ \\
\hline Between & $92 / 562$ & 1.29 & $1.00-1.66$ & $69 / 593$ & 1.14 & $0.85-1.52$ \\
\hline Healthy & $103 / 843$ & 1.00 & - & $84 / 873$ & 1.00 & - \\
\hline \multicolumn{7}{|l|}{ Job strain } \\
\hline High strain & $77 / 438$ & 1.19 & $0.89-1.60$ & $64 / 373$ & 1.96 & $1.36-2.84$ \\
\hline Low strain & $65 / 433$ & 0.95 & $0.70-1.29$ & $37 / 454$ & 1.07 & $0.71-1.62$ \\
\hline Passive & $167 / 870$ & 1.08 & $0.83-1.41$ & $96 / 599$ & 1.62 & $1.14-2.31$ \\
\hline Active & $73 / 567$ & 1.00 & - & $46 / 686$ & 1.00 & - \\
\hline \multicolumn{7}{|l|}{ Social support at work } \\
\hline Little & $148 / 680$ & 1.36 & $1.07-1.72$ & $105 / 576$ & 1.56 & $1.15-2.12$ \\
\hline Somewhat & $136 / 835$ & 1.11 & $0.88-1.42$ & $81 / 811$ & 1.02 & $0.74-1.40$ \\
\hline A great deal & $98 / 793$ & 1.00 & - & $57 / 725$ & 1.00 & - \\
\hline \multicolumn{7}{|l|}{ Employment history } \\
\hline At least temporary unemployed & 194/1082 & 1.02 & $0.85-1.22$ & $101 / 751$ & 1.10 & $0.87-1.39$ \\
\hline Continuously employed & $188 / 1226$ & 1.00 & - & $142 / 1361$ & 1.00 & - \\
\hline
\end{tabular}

Multivariate logistic regression analyses adjusted for gender and all other variables in the table, risk ratios (RR) and 95\% confidence intervals (CI)

Italics show those RR values, which are statistically significant work groups. Psychological strain was associated with poor perceived work ability in the light work group but not in the strenuous work group. With the exception of poor health habits, the relative risk estimates of the other covariates were lower in strenuous work group than in the light work group (Table 3). 


\section{Discussion}

This study involving a large population-based birth cohort and covering men and women in all occupational groups and branches of economy showed that perceived work ability decreased from the age of 31 to 46 in both physically strenuous and light work, and was the lowest among participants with physically strenuous work. The participants whose work remained physically strenuous during the 15 -year follow-up period perceived their work ability as the worst. Those for whom work had a low personal meaning were at approximately a twofold risk of having poor perceived work ability at 46 years compared to those who reported that work has a high personal meaning to them, in both physically strenuous and light work groups.

\section{The course of work ability from 31 to 46 years}

The findings of Ilmarinen et al. (1997) are in line with the findings of the present study. In that 11-year follow-up study, perceived work ability of aging municipal workers decreased more among those doing physical work compared those doing mental work. The proportion of poor perceived work ability among 31-year-old men with physically strenuous work in this study was about the same level as that reported among 35-year-old operative firefighters (11\% and 17\%, respectively) (Punakallio et al. 2014). The participants whose work remained strenuous during the 15-year followup period reported their work ability to be over 8 (scale of 1-10, 8.3 among men and 8.4 among women), which was a slightly better rating than that among firefighters aged 40-49, who reported work ability of an average of 7.4 (LusaMoser at al. 1997). In the strenuous work group, perceived work ability remained always poor or diminished in $22 \%$ of men, which is almost the same trend as that found among firefighters, of whom $24 \%$ belonged to the declining work ability trajectory during the 13-year follow-up (Punakallio et al. 2014).

We would like to note that despite generally declining perceived work ability over 15 years, most participants, irrespective of the physical strenuousness of their work, perceived their work ability as good. This is also in line with studies of municipal workers, managers and firefighters, of which-despite an overall declining trend-the majority belonged to favorable work ability trajectories (Feldt et al. 2009; Ilmarinen et al. 1997; Punakallio et al. 2014; von Bonsdorff et al. 2011). The high, diverse work demands of physically strenuous work require workers to have good work ability. In the future, more intensive interventions are needed especially among those with decreased work ability already at their early thirties.

\section{Factors associated with work ability}

Low personal meaning of work was significantly associated with poor perceived work ability in both the strenuous work and light work groups, despite adjusting for confounders (number of diseases, health habits, job strain, social support at work, and employment history). We found no earlier studies on the relation between personal meaning of work and work ability among middle-aged workers. Earlier, a more task-related meaning of work, indicating that the work tasks are experienced as meaningful and the results of work as important and useful for others (Kristensen et al. 2005), has been studied as a possible predictor of work absences among eldercare workers (Nielsen et al. 2002, 2004; Tufte et al. 2012), with no clear relation between the experienced meaningfulness of the current work and work absence. Instead, work engagement, another positive work-related motivational concept, has been found to associate with work ability among Finnish firefighters (Airila et al. 2012). Airila et al. (2012) found that during a 10-year follow-up, work engagement was significantly associated with work ability, even after adjusting for several individual and work-related factors such as physical workload. Our results add to the earlier evidence by suggesting that also a more generic positive personal meaning of work seems to have a positive influence on work ability.

Of the other potential predictors, two or more diseases, unhealthy habits and low social support at work were independently related to poor perceived work ability. This accords with the previous findings among workers in physically demanding jobs that many diseases, unhealthy lifestyle habits and poor relationships between workers and supervisors were risk factors for diminished work ability (Lusa et al. 2011; Airila et al. 2012; Punakallio et al. 2014). In this study, a psychosocially high strain job was associated with poor work ability among participants in the light work group, but not in the strenuous work group. This may be because work in the light work group is possibly mentally more demanding than that in the strenuous work group.

With the exception of poor health habits, the risk estimates for the covariates, especially for the number of diseases, were lower in the strenuous work group than in the light work group. One reason for this minor significance of diseases in the strenuous work group compared to the light work group may be that the workers with many diseases had already been excluded (from work and the data). It may be impossible to manage physical tasks with two or more diseases. Previously, both a higher number of comorbid diseases and a high physical workload were shown to be risk factors for disability pension among firefighters (Punakallio et al. 2014). We were somewhat surprised that psychosocial stress factors were associated with perceived work ability in only the light work group, although earlier findings on 
white-collar workers have shown them to be major factors affecting work ability (e.g. van den Berg et al. 2008).

In an earlier cross-sectional study with different occupations, van den Berg et al. (2011) studied the importance of job control for workers with decreased work ability to remain productive at work. They found that high physical work demands appeared less important for productivity loss at work than psychosocial work characteristics. Alavinia et al. (2009) and Martimo et al. (2009) found similar results. Van den Berg at al. (2011) concluded that job control and related possibilities to adjust work could act as a buffer in highly physically demanding jobs. Nevertheless, in this study, the importance of high personal meaning of work for good work ability was evident, regardless of the level of physical strenuousness of the work.

\section{Study strengths and limitations}

The major strengths of this study included the prospectively collected data and the long follow-up time of 15 years. The data were obtained from a large birth cohort and covered all branches of occupations and sectors of the economy. The men and women were combined and analyses were adjusted for gender. The prospective study setting allowed us to investigate the long-term course of work. However, a loss of participants occurred, as only those living in northern Finland and the metropolitan area were invited to reply to the work-related questions at 31 years. Although the participation rates were high at both 31 and 46 years, the sample size of those who participated in both measurements was smaller. Thus, associations between personal meaning of work and work ability were calculated using a cross-sectional design at the age of 46 only. Although we could adjust our analyses for several covariates, unmeasured residual confounding as well as common method bias always remain possible in an observational study like ours.

Some selection bias occurred, as those excluded from the analyses significantly more often had decreased perceived work ability, unhealthy habits and tended to more often belong to the strenuous work group than the included participants. Some healthy worker effect also occurred. Because the proportions of those with physically strenuous work and poor perceived work ability were higher among the dropouts, this bias probably somewhat attenuated the observed associations.

\section{Practical implications}

These results have several implications for the promotion of work ability at workplaces, in occupational health care and in society. First, the experience of personal meaning of work appears to be important for work ability in all work. Evaluating the practical possibilities for and methods of externally enhancing an individual's internally perceived personal meaning of work is beyond the scope of this study, but given the magnitude of the challenge of extending working careers, further studies on this issue are warranted, using different methods. Personal meaning of work is a generic overall perception of the role of work in one's life and probably a long-lasting attitude towards work. It is likely that personal meaning of work rather slowly develops during the life course in various social contexts. Earlier results using this same cohort support this assumption by showing that school performance at age 16 years predicted high personal meaning of work at 31 years among both genders (Ek et al. 2005). The perceptions of personal meaning of work could possibly to some extent be enhanced at work by providing feedback on the larger benefits one's work has on, e.g. clients or society, or by helping workers experience success in regard to the goals that are personally important for them. In any case, our results support the idea of highlighting the individual workers' personal values regarding work in understanding the development of their work ability. Second, since a fifth of the workforce in physically strenuous work presents a notable decline in their work ability already before the age of 46 , with at least 20 years before the current statutory retirement age, it is imperative that the actions of disability prevention are begun early and intensively enough at workplaces and in occupational health care; especially by promoting healthy habits among workers in physically strenuous work.

\section{Conclusions}

Perceived work ability was significantly lower and deteriorated more over 15 years' follow-up in middle age among the participants with physically strenuous compared to those with light work. Personal meaning of work was important for good work ability in both physically strenuous work and light work, and should, therefore, be taken into account in work ability promotion at workplaces and in occupational health care.

Acknowledgements We thank the late Professor Paula Rantakallio for initiating the Northern Finland Birth Cohort study and Ms Alice Lehtinen for revising the language of the manuscript. The study was funded by The Finnish Work Environment Fund (111252) and by the Strategic Research Council (SRC) at the Academy of Finland (303430). The data collection of the 1966 Northern Finland Birth Cohort was financially supported by the European Commission (EURO-BLCS, Framework 5 award QLG1-CT-2000-01643), the US National Institutes of Health (NIMH) (5R01MH63706:02), the EU (European Regional Development Fund), the Oulu University Hospital, and the University of Oulu.

\section{Compliance with ethical standards}

Conflict of interest All authors declare that they have no conflict of interest. 
OpenAccess This article is distributed under the terms of the Creative Commons Attribution 4.0 International License (http://creativeco mmons.org/licenses/by/4.0/), which permits unrestricted use, distribution, and reproduction in any medium, provided you give appropriate credit to the original author(s) and the source, provide a link to the Creative Commons license, and indicate if changes were made.

\section{References}

Ahlström L, Grimby-Ekman A, Hagberg M, Dellve L (2010) The Work Ability Index and single-item question: associations with sick leave, symptoms, and health-a prospective study of women on long-term sick leave. Scand J Work Environ Health 36(5):404412. https://doi.org/10.5271/sjweh.2917

Airila A, Hakanen J, Punakallio A, Lusa S, Luukkonen R (2012) Is work engagement related to work ability beyond working conditions and lifestyle factors? Int Arch Occup Environ Health 85:915-925. https://doi.org/10.1007/s00420-012-0732-1

Alavinia SM, Molenaar D, Burdof A (2009) Productivity loss in the workforce: associations with health, work demands, and individual characteristics. Am J Ind Med 52:49-56. https://doi. org/10.1002/ajim.20648

Clausen T, Burr H, Borg V (2014) Does affective organizational commitment and experience of meaning at work predict risk of disability pensioning? An analysis of register-based outcomes using pooled data on 40,554 observations in four occupational groups. Am J Ind Med 57:709-717. https://doi.org/10.1002/ajim.22313

de Zwart BCH, Frings-Dresen MHW, van Duivenbooden JC (2002) Test-retest reliability of the Work Ability Index questionnaire. Occup Med 52:177-181. https://doi.org/10.1093/occmed/52.4.177

Ek E, Sovio U, Remes J, Järvelin M-R (2005) Social predictors of unsuccessful entrance into labour market - a socialization process perspective. J Vocat Behav 66(3):471-486. https://doi. org/10.1016/j.jvb.2004.02.002

El Fassi M, Bocquet V, Majery N, Lair ML, Couffignal S, Mairiaux P (2013) Work ability assessment in a worker population: comparison and determinants of Work Ability Index and Work Ability score. BMC Public Health 13:305. https://doi. org/10.1186/1471-2458-13-305

Feldt T, Hyvönen K, Mäkikangas A, Kinnunen U, Kokko K (2009) Development trajectories of Finnish managers' work ability over a 10-year follow-up period. Scand J Work Environ Health 35:37-47. https://doi.org/10.5271/sjweh.1301

Folkman S, Lazarus RS (1985) If it changes it must be a process: a study of emotional and coping during three stages of a college examination. J Pers Soc Psychol 48:150-170. https://doi. org/10.1037/0022-3514.48.1.150

Frankl VE (1963) Man's search for meaning. NY Pocket Books, New York

Gould R, Ilmarinen J, Järvisalo J, Koskinen S (2008) Factors affecting work ability. In: Gould R, Ilmarinen J, Järvisalo J, Koskinen S (eds) Dimensions of work ability: results of the health 2000 survey. Finnish Centre of Pensions, The Social Insurance Institution, National Public Health Institute, Finnish Institute of Occupational Health, Helsinki, pp 63-107

Ilmarinen J (2006) Towards a longer worklife! Ageing and the quality of worklife in the European Union. Finnish Institute of Occupational Health, Ministry of Social Affairs and Health, Helsinki

Ilmarinen J, Tuomi K (2004) Past, present and future of work ability. In: Ilmarinen J, Lehtinen S (eds) Past, present and future work ability. Finnish institute of occupational health, Helsinki, people and work research reports 65 , pp 1-25
Ilmarinen J, Tuomi K, Klockars M (1997) Changes in the work ability of active employees over an 11-year period. Scand J Work Environ Health 23:49-57

Ilmarinen J, Tuomi K, Seitsamo J (2005) New dimensions of work ability. In: Costa G, Goedhard WJA and Ilmarinen J (eds) Assessment and promotion of work ability, health and well-being of ageing workers. International Congress Series 1280, Elsevier, The Netherlands, pp 3-7

Jääskeläinen A, Nevanperä N, Remes J, Rahkonen F, Järvelin MR, Laitinen J (2014) Stress-related eating, obesity and associated behavioral traits in adolescents: a prospective population-based cohort study. BMC Public Health 14:321-335. https://doi. org/10.1186/1471-2458-14-321

Järvelin MR, Sovio U, King V, Lauren L, Xu B, McCarthy MI, Hartikainen AL, Laitinen J, Zitting P, Rantakallio P, Elliott P (2004) Early life factors and blood pressure at age 31 years in the 1966 northern Finland birth cohort. Hypertension 44(6):838-846. https://doi.org/10.1161/01.HYP.0000148304.33869.ee

Kahn H, Wiener A (1967) The year 2000. Macmillan, London

Karasek R, Brisson C, Kawakami N, Houtman I, Bongers P, Amick B (1998) The job content questionnaire (JCQ): an instrument for psychosocial job characteristics. J Occup Health Psychol 3(4):322-355. https://doi.org/10.1037/1076-8998.3.4.322

Kristensen TS, Hannerz H, Hogh A, Borg V (2005) The Copenhagen Psychosocial Questionnaire-a tool for the assessment and improvement of the psychosocial work environment. Scand J Environ Health 31(6):438-449. https://doi.org/10.5271/sjweh .948

Kujala V, Remes J, Ek E, Tammelin T, Laitinen J (2005) Classification of Work Ability Index among young employees. Occup Med (Lond) 55(5):399-401. https://doi.org/10.1093/occmed/kqi075

Kujala V, Tammelin T, Remes J, Vammavaara E, Ek E, Laitinen J (2006) Work Ability Index of young employees and their sickness absence during the following year. Scand J Environ Health 32:75-84. https://doi.org/10.5271/sjweh.979

Laaksonen M, Prättälä R, Karisto A (2001) Patterns of unhealthy behaviour in Finland. Eur J Public Health 11:294-300. https:// doi.org/10.1093/eurpub/11.3.294

Laitinen J, Ek E, Sovio U (2002) Stress-related eating and drinking behavior and body mass index and predictors of this behavior. Prev Med 34:29-39. https://doi.org/10.1006/pmed.2001.0948

Lazarus RS, Folkman S (1984) Stress, appraisal, and coping. Springer, New York

Lederer V, Loisel P, Rivard M, Champagne F (2014) Exploring the diversity of conceptualizations of work (dis)ability: a scoping review of published definitions. J Occup Rehabil 24:242-267. https://doi.org/10.1007/s10926-013-9459-4

Lusa S, Punakallio A, Luukkonen R (2011) Factors predicting perceived work ability of Finnish firefighters. In: Nygård C-H, Savinainen M, Kirsi T, Lumme-Sandt K (eds) Age management during the life course, proceedings of the 4th symposium on work ability, 2010 June 6-9, Tampere, Finland, Tampere university press, pp 61-169

Lusa-Moser S, Punakallio A, Louhevaara V, Viikari-Juntura E, Ilmarinen R, Ollila J, Korhonen O, Lindqvist-Virkamäki S, Luukkonen R (1997) Eri-ikäisten palomiesten terveys ja toimintakyky, osa 1: Kyselytutkimus - elintapojen, terveydentilan ja psyykkisten tekijöiden yhteydet koettuun työkykyyn. Helsinki, Työterveyslaitos. Ikääntyvä arvoonsa - työterveyden, työkyvyn ja hyvinvoinnin edistämisohjelman julkaisuja 30. In Finnish

Martimo KP, Shiri R, Miranda H, Ketola R, Varonen H, ViikariJuntura E (2009) Self-reported productivity loss among workers with upper extremity disorders. Scand J Work Environ Health 35:301-308. https://doi.org/10.5271/sjweh.1333

Nevanperä N, Ala-Mursula L, Seitsamo J, Remes J, Auvinen J, Hopsu L, Husman P, Karppinen J, Järvelin MR, Laitinen J (2015) 
Long-lasting obesity predicts poor work ability at midlife: a 15-year follow-up of the northern Finland 1966 Birth Cohort Study. J Occup Environ Med 57(12):1262-1268. https://doi. org/10.1097/JOM.0000000000000579

Nevanperä N, Seitsamo J, Ala-Mursula L, Remes J, Hopsu L, Auvinen J, Tammelin T, Järvelin MR, Laitinen J (2016) Perceived work ability in the light of long-term and stress-related unhealthy behaviors-a prospective cohort study. Int J Behav Med 23(2):179189. https://doi.org/10.1007/s12529-015-9512-0

Nielsen ML, Kristensen TS, SmithHansen L (2002) The intervention project on absence and well-being (IPAW): design and results from the baseline of a 5-year study. Work Stress 16:191-206. https ://doi.org/10.1080/02678370210164003

Nielsen ML, Rugulies R, Christensen KB, Smith-Hansen L, Bjorner JB, Kristensen TS (2004) Impact of the psychosocial work environment on registered absence from work: a two-year longitudinal study using the IPAW cohort. Work Stress 18:323-335. https:// doi.org/10.1080/02678370412331324806

O'Connor K, Chamberlain K (1996) Dimensions of life meaning: a qualitative investigation at mid-life. Br J Psychol 87:461-477. https://doi.org/10.1111/j.2044-8295.1996.tb02602.x

Pensola T, Gould R, Polvinen A (2010) Ammatit ja työkyvyttömyyseläkkeet. Masennukseen, muihin mielenterveyshäiriöihin ja tuki- ja liikuntaelinten sairauksiin perustuvat eläkkeet. Sosiaali- ja terveysministeriön selvityksiä 16, Helsinki. In Finnish, English summary. http://urn.fi/URN:ISBN:978-952-00-3009-4

Punakallio A, Lusa S, Luukkonen R, Lindholm H (2011) Physical capacities for predicting the perceived work ability of firefighters. In: Nygård C-H, Savinainen M, Kirsi T, Lumme-Sandt K (eds) Age management during the life course, proceedings of the 4th symposium on work ability, 2010 June 6-9, Tampere, Finland, Tampere University Press, pp 150-160

Punakallio A, Lusa S, Luukkonen R, Airila A, Leino-Arjas A (2014) Musculoskeletal pain and depressive symptoms as predictors of trajectories in work ability among finnish firefighters at 13 -year follow-up. J Occup Environ Med (56)4:367-375. https://doi. org/10.1097/JOM.0000000000000139

Rantakallio P (1969) Groups at risk in low birth weight infants and perinatal mortality. In: A prospective study of the biological characteristics and socioeconomic circumstances of mothers in 12,000 deliveries in North Finland 1966. A discriminant function analysis, Oulu

Rantakallio P (1988) The longitudinal study of the northern Finland birth cohort of 1966. Paediatr Perinat Epidemiol 2:59-88. https ://doi.org/10.1111/j.1365-3016.1988.tb00180.x

Roelen CA, Heymans MW, Twisk JW, van der Klink JJ, Groothoff JW, van Rhenen W (2014) Work Ability Index as tool to identify workers at risk of premature work exit. J Occup Rehabil 24(4):747754. https://doi.org/10.1007/s10926-014-9505-x

Sell L, Bültmann U, Rugulies R, Villadsen E, Faber A, Søgaard K (2009) Predicting long-term sickness absence and early retirement pension from self-reported work ability. Int Arch Occup Environ Health 82(9):1133-1138. https://doi.org/10.1007/s0042 0-009-0417-6

Tammelin T, Näyhä S, Hills AP, Järvelin M-R (2003) Adolescent participation in sports and adults physical activity. Am J Prev Med 24(1):22-28. https://doi.org/10.1016/S0749-3797(02)00575-5

Tufte P, Clausen T, Nabe-Nielsen K (2012) Client-related work tasks and meaning of work: results from a longitudinal study among eldercare workers in Denmark. Int Arch Occup Environ Health 85:467-472. https://doi.org/10.1007/s00420-011-0692-x

Tuomi K, Eskelinen J, Toikkanen J, Järvinen E, Ilmarinen J, Klockars M (1991) Work load and individual factors affecting work ability among aging municipal employees. Scand J Work Environ Health $17: 128-134$

Tuomi K, Ilmarinen J, Seitsamo J, Huuhtanen P, Martikainen R, Nygård C-H, Klockars M (1997) Summary of the Finnish research project (1981-1992) to promote the health and work ability of ageing workers. Scand J Work Environ Health 23:66-71

Tuomi K, Ilmarinen J, Jahkola A, Katajarinne L, Tulkki A (2006) Work Ability Index. Occupational Health Care nro 19, 2nd revised edition. Finnish institute of occupational health, Helsinki

van den Berg TI, Alavinia SM, Bredt FJ, Lindeboom D, Elders LA, Burdorf A (2008) The influence of psychosocial factors at work and life style on health and work ability among professional workers. Int Arch Occup Environ Health 81:1029. https://doi. org/10.1007/s00420-007-0296-7

van den Berg TI, Elders LA, de Zwart BC, Burdorf A (2009) The effects of work-related and individual factors on the Work Ability Index: a systematic review. Occup Environ Med 66(4):211-220. https://doi.org/10.1136/oem.2008.039883

van den Berg TI, Robroek SJ, Plat JF, Koopmanschap MA, Burdorf A (2011) The importance of job control for workers with decreased work ability to remain productive at work. Int Arch Occup Environ Health 84:705-712. https://doi.org/10.1007/s00420-010-0588-1

von Bonsdorff ME, Kokko K, Seitsamo J, von Bonsdorff MB, Nygård C-H, Ilmarinen J, Rantanen T (2011) Work strain in midlife and 28-year work ability trajectories. Scand J Work Environ Health 37:455-463. https://doi.org/10.5271/sjweh.3177

von Bonsdorff MB, Seitsamo J, Ilmarinen J, Nygård CH, von Bonsdorff ME, Rantanen T (2012) Work ability as a determinant of old age disability severity: evidence from the 28-year Finnish longitudinal study on municipal employees. Aging Clin Exp Res 24(4):354360. https://doi.org/10.3275/8107

Publisher's Note Springer Nature remains neutral with regard to jurisdictional claims in published maps and institutional affiliations. 